UDC 332.1

LBC 65.05

\title{
RUSSIAN AND FOREIGN PRACTICE OF VALUATING MUNICIPAL REAL ESTATE ${ }^{1}$
}

\author{
Oleg V. Likhomanov \\ Volgograd State University, Volgograd, Russian Federation \\ Natalya E. Kukanova \\ Volgograd Regional Branch of All-Russian Organization “Russian Society of Appraisers”,
Volgograd, Russian Federation
}

Mariya S. Kukanova

Volgograd State University, Volgograd, Russian Federation

\begin{abstract}
The authors analyze the real estate tax system of England, France, Germany, the USA, Canada, Sweden, Denmark, Holland, Spain, Portugal, Poland, Chile, Singapore, the Philippines, and Japan. The following activities are proposed with the aim of creating an effective system of municipal real estate management and improving the quality of local government: to organize the smooth functioning of full and timely accounting of the municipal real estate, the introduction of an automated registry system, including legal, technical, and economic components of records; to develop scientifically based optimal management solutions on the disposal of municipal property, in compliance with the balance of fiscal, investment and socially-oriented objectives in the course of operational management, transfer in use or trust, disposition, use as the authorized capital; to develop the optimal solutions for selecting strategies for achieving maximum economic efficiency and increasing investment attractiveness of municipal property; to exercise effective control over regulatory use of municipal property (especially land resources) for its intended purpose; to organize work on reliable cadastral valuation of the property; to provide the state budget institutions for cadastral valuation established in the regions with qualified personnel from among the practicing independent appraisers; to engage independent appraisers for analysis and monitoring of real estate market with the aim of identifying pricing factors and ensuring reliable results, compliant with relevant market data; to completely eliminate the possibility of pressure by officials of local self-government bodies at the state budget institutions for the cadastral valuation to establish the desired orientations of the cadastral value. The authors propose to initiate the - introduction of uniform date of establishment of the cadastral value on the territory of the Russian Federation with the aim of providing a single investment area; the establishment the tax base for land tax and property tax at the level of 50$75 \%$ of the cadastral (close to market) value with the aim of identifying the optimal tax base on the basis of the principles of equity and proportionality of taxation (as an experiment in several regions of the Russian Federation).

Key words: cadastral value, market value, real estate appraisal, property tax, rents, property management.
\end{abstract}

УДК 332.1

ББК 65.05

\section{РОССИЙСКАЯ И ЗАРУБЕЖНАЯ ПРАКТИКА ОЦЕНКИ МУНИЦИПАЛЬНОЙ НЕДВИЖИМОСТИ ${ }^{1}$}

\author{
Олег Владимирович Лихоманов
}

Волгоградский государственный университет, г. Волгоград, Российская Федерация

Наталья Евгеньевна Куканова

Волгоградское областное отделение Общероссийской организации «Российское общество оценщиков», г. Волгоград, Российская Федерация 


\section{Мария Сергеевна Куканова}

Волгоградский государственный университет, г. Волгоград, Российская Федерация

Аннотация. Анализируются системы налогообложения недвижимости Англии, Франции, Германии, США, Канады, Швеции, Дании, Голландии, Испании, Португалии, Польши, Чили, Сингапура, Филиппин, Японии. С целью создания эффективной системы управления муниципальным недвижимым имуществом и совершенствования качества местного самоуправления предложены следующие мероприятия: организовать бесперебойное функционирование полноценного и своевременного учета муниципального недвижимого имущества, внедрение автоматизированной системы ведения реестров, включая правовую, техническую и экономическую составляющую учета; разработать научно обоснованные оптимальные управленческие решения по распоряжению имущества, находящегося в муниципальной собственности, при соблюдении баланса фискальных, инвестиционных и социально ориентированных целей, при оперативном управлении, передаче в пользование или доверительное управление, отчуждении, использовании в качестве уставного капитала; разработать оптимальные решения для выбора стратегий по достижению максимальной экономической эффективности использования и повышения инвестиционной привлекательности муниципальной недвижимости; осуществлять эффективный контроль за нормативным использованием муниципального имущества (особенно земельных ресурсов) по его назначению; организовать работы по определению достоверной величины кадастровой стоимости недвижимости; обеспечить государственные бюджетные учреждения по оценке кадастровой стоимости, создаваемые в регионах, квалифицированными кадрами из числа практикующих независимых оценщиков; привлечь независимых оценщиков для анализа и мониторинга рынка недвижимости с целью выявления ценообразующих факторов и обеспечения достоверных результатов, соответствующих рыночным данным; полностью исключить возможности давления должностных лиц органов местного самоуправления на государственные бюджетные учреждения по оценке кадастровой стоимости с целью установления желательных ориентиров кадастровой стоимости. Предложено инициировать: введение единой даты установления кадастровой стоимости на территории Российской Федерации с целью обеспечения единого инвестиционного пространства; установление, в качестве эксперимента, в нескольких регионах РФ налоговой базы для земельного налога и налога на имущество на уровне 50-75 \% от кадастровой (приближенной к рыночной) стоимости с целью выявления оптимальной налоговой базы налогоплательщиков исходя из принципов справедливости и соразмерности налогообложения.

Ключевые слова: кадастровая стоимость, рыночная стоимость, оценка недвижимости, налог на недвижимость, арендные ставки, управление собственностью.

Одной из самых сложных и ответственных задач управления муниципальной собственностью является управление доходными видами собственности: землей, жилой и коммерческой недвижимостью.

В большинстве стран основными способами наполнения бюджета являются налоги на недвижимую собственность (в Японии и США - это имущественный налог, в Германии и Франции - поземельный и налог на жилую и коммерческую недвижимость, налог на недвижимость и на увеличение стоимости городских земель в Испании). Собранные таким образом налоги на недвижимость остаются исключительно в ведении муниципалитетов и представляют собой основной финансовый ресурс для выполнения социальных обязательств перед населением.

Объектами налогообложения служат городские и сельскохозяйственные земельные участки, жилые и промышленные здания и со- оружения, другие виды недвижимости. Базой налогообложения являются кадастровая, рыночная или инвентаризационная стоимость недвижимого имущества. Налоговые ставки устанавливаются в виде процентного отношения от налогооблагаемой базы или в виде регламентирующей ставки от единицы стоимости имущества. В отличие от других видов налога, налог на недвижимое имущество является гарантированным источником дохода, поскольку местоположение и юрисдикция объектов недвижимости легко фиксируется и администрируется.

В современных условиях, когда количество муниципальной собственности (земельных участков, зданий и сооружений) сокращается в связи с переходом ее в собственность граждан, ситуация в финансовой и социальной сферах в муниципальных образованиях определяется тем, насколько правильно производится управление (в том числе определение кадастровой стоимости недвижимости как 
налогооблагаемой базы) оставшимися объектами муниципальной собственности.

В конце 2016 г. сразу несколько крупных застройщиков уведомили власти Волгоградской области об отказе от аренды земельных участков и остановке строительных проектов. По сравнению с 2015 г. объем построенного жилья снизился на $18 \%$. Год назад происходил аналогичный спад. За последние два года темпы строительства домов заметно снизились, и по сравнению с 2014 г. упали почти на $35 \%$. В целом объем всех строительных работ, выполненных в 2016 г. на территории региона, упал за год на 12,4 \%. По результатам деятельности строительных организаций в 2017 г. ожидается снижение объемов вводимого жилья в Волгоградской области примерно на $15 \%$. В случае если налоговая база на недвижимость не будет способствовать получению расчетной дисконтированной чистой прибыли и ожидаемой доходности инвестора, муниципальная казна потеряет не только собственников (так как многие будут вынуждены продавать объекты в силу высокого налогового бремени), но и арендаторов, а также потенциальных покупателей объектов.

Авторами статьи предпринята попытка систематизировать наиболее характерные черты и особенности, присущие системам налогообложения недвижимости в Российской Федерации и за рубежом (см. таблицу).

Следует отметить, что налоговой базой по налогу на недвижимость в зарубежных странах является не собственно рыночная стоимость, а так называемая оценочная стоимость, обычно находящаяся на уровне $50 \%$ от рыночной стоимости (как в США и Канаде), но иногда достигающая и $75 \%$ (как в Швеции), или даже 80 \% (как во Франции в отношении незастроенных участков).

Такой подход видится разумным, особенно с учетом негативного опыта оспаривания кадастровой стоимости в РФ в последние годы, когда факты превышения кадастровой стоимости над рыночной достигали сотен процентов [2]. Конечно, методы массовой оценки, которыми рассчитывается кадастровая стоимость, не могут учесть индивидуальных особенностей каждого объекта. При имеющихся недостатках в учете муниципального недвижимого имущества и рынке недвижимо- сти, который переживает стадию стагнации, вновь созданные государственные бюджетные учреждения по оценке кадастровой стоимости вряд ли смогут избавиться от унаследованных от прежней системы недостатков. Именно поэтому, во избежание новой волны оспаривания, целесообразно было бы позаимствовать опыт определения налоговой базы на уровне $50-75 \%$ от кадастровой (приближенной к рыночной) стоимости.

Налогоплательщиками и в России и за рубежом являются собственники недвижимости, однако в ряде стран налогоплательщиками являются и арендаторы, пользователи объектов недвижимости.

Процесс оценки объектов недвижимости для налогообложения производится специальными органами государственной оценки или муниципальными налоговыми органами (Кадастровое управление Испании, Центры оценки недвижимости штатов Канады). Существует и практика оценки объектов недвижимости по заданиям муниципальных органов профессиональными оценщиками (отдельные штаты США). Но налогоплательщикам зарубежных стран предоставлено право на оспаривание оценки объектов имущества в целях снижения налоговых ставок, а массовая регулярная переоценка собственности производится периодически через определенные промежутки времени или даже (как, например, в Канаде) ежегодно.

\section{Выводы и рекомендации}

Проведенный анализ действующей российской и зарубежной практик налогообложения недвижимости наглядно демонстрирует существенноепринципиальное различие между ними.

Если в экономически развитых странах земля, отдельные виды муниципальных предприятий и недвижимости обычно относятся к категории высокодоходных видов муниципальной собственности, то в Российской Федерации вследствие проблем в централизованной системе оценки экономическая ситуация выглядит нелогично. Убыточными в Российской Федерации являются даже такие традиционно доходные виды деятельности в мировой практике, как аренда жилья, тепло- и водоснабжение. Необходимо переходить на современные формы управления муниципальной собственностью. 
Системы налогообложения недвижимости в Российской Федерации и за рубежом

Таблиияа

\begin{tabular}{|c|c|c|c|c|c|c|}
\hline Страна & Вид налога & \begin{tabular}{|c|}
$\begin{array}{c}\text { Получатель } \\
\text { налога }\end{array}$ \\
\end{tabular} & $\begin{array}{c}\text { Налогообла- } \\
\text { гаемая база }\end{array}$ & Ставка налога & $\begin{array}{l}\text { Объект нало- } \\
\text { гообложения }\end{array}$ & $\begin{array}{c}\text { Плательщик } \\
\text { налога }\end{array}$ \\
\hline \multirow[t]{4}{*}{$\begin{array}{l}\text { Россий- } \\
\text { ская Фе- } \\
\text { дерация }\end{array}$} & $\begin{array}{l}\text { Земельный } \\
\text { налог [9] }\end{array}$ & \begin{tabular}{|l} 
Местный \\
бюджет
\end{tabular} & $\begin{array}{l}\text { Кадастровая } \\
\text { стоимость }\end{array}$ & $\begin{array}{l}\text { Устанавливается органами му- } \\
\text { ниципальных образований и не } \\
\text { может превышать: } \\
\text { Максимальные ставки, устанав- } \\
\text { ливаемые органами муници- } \\
\text { пальных образований: } \\
\text { - для земельных участков сель- } \\
\text { скохозяйственного назначения - } \\
0,3 \text { \%; } \\
\text { - для земельных участков жи- } \\
\text { лищного фонда и объектов ин- } \\
\text { женерной инфраструктуры жи- } \\
\text { лищно-коммунального комплек- } \\
\text { са - 0,3 \%; } \\
- \text { для земельных участков лич- } \\
\text { ного подсобного и дачного хо- } \\
\text { зяйства, животноводства, садо- } \\
\text { водства, огородничества - } 0,3 \text { \%; } \\
- \text { для земельных участков про- } \\
\text { чих земельных участков - } 1,5 \text { \% }\end{array}$ & $\begin{array}{l}\text { Земельные } \\
\text { участки }\end{array}$ & $\begin{array}{l}\text { Собственни- } \\
\text { ки земельных } \\
\text { участков и } \\
\text { пользователи } \\
\text { по праву по- } \\
\text { жизненно на- } \\
\text { следуемого } \\
\text { владения }\end{array}$ \\
\hline & $\begin{array}{l}\text { Земельный } \\
\text { налог г. } \\
\text { Волгограда } \\
{[12]}\end{array}$ & $\begin{array}{l}\text { Местный } \\
\text { бюджет }\end{array}$ & $\begin{array}{l}\text { Кадастровая } \\
\text { стоимость }\end{array}$ & $\begin{array}{l}\text { Устанавливается на уровне мак- } \\
\text { симальных ставок }\end{array}$ & $\begin{array}{l}\text { Земельные } \\
\text { участки }\end{array}$ & $\begin{array}{l}\text { Собственни- } \\
\text { ки земельных } \\
\text { участков и } \\
\text { пользователи } \\
\text { по праву по- } \\
\text { жизненно на- } \\
\text { следуемого } \\
\text { владения }\end{array}$ \\
\hline & \begin{tabular}{|l|} 
Налог на \\
имущество \\
организаций \\
[9]
\end{tabular} & \begin{tabular}{|l} 
Местный \\
бюджет
\end{tabular} & $\begin{array}{l}\text { Кадастровая } \\
\text { или среднего- } \\
\text { довая стои- } \\
\text { мость имуще- } \\
\text { ства }\end{array}$ & $\begin{array}{l}\text { В случае использования кадастро- } \\
\text { вой стоимости - } 2 \text { \%. } \\
\text { В случае использования среднего- } \\
\text { довой стоимости имущества мак- } \\
\text { симальная ставка налога, устанав- } \\
\text { ливаемая субъектами Российской } \\
\text { Федерации - } 2,2 \%\end{array}$ & $\begin{array}{l}\text { Имущество } \\
\text { (недвижимое } \\
\text { и движимое) }\end{array}$ & $\begin{array}{l}\text { Организации, } \\
\text { имеющие } \\
\text { объекты на- } \\
\text { логообложе- } \\
\text { ния }\end{array}$ \\
\hline & $\begin{array}{l}\text { Налог на } \\
\text { имущество } \\
\text { физических } \\
\text { лиц [9] }\end{array}$ & $\begin{array}{l}\text { Местный } \\
\text { бюджет }\end{array}$ & $\begin{array}{l}\text { Кадастровая } \\
\text { или инвента- } \\
\text { ризационная } \\
\text { стоимость }\end{array}$ & $\begin{array}{l}\text { Максимальные ставки, устанав- } \\
\text { ливаемые органами муници- } \\
\text { пальных образований: } \\
\text { - для жилых домов и помещений, } \\
\text { единых недвижимых комплексов, } \\
\text { гаражей и хозяйственных строе- } \\
\text { ний, расположенных на земель- } \\
\text { ных участках - } 0,1 \text { \%; } \\
\text { - для административно-деловых } \\
\text { и торговых центров - } 2 \text { \%; } \\
- \text { для прочих объектов налого- } \\
\text { обложения - 0,5 \% }\end{array}$ & $\begin{array}{l}\text { Жилой дом; } \\
\text { квартира, га- } \\
\text { раж, единый } \\
\text { недвижимый } \\
\text { комплекс } \\
\text { (в том числе } \\
\text { незавершен- } \\
\text { ное строи- } \\
\text { тельсто) }\end{array}$ & $\begin{array}{l}\text { Собственни- } \\
\text { ки имущества }\end{array}$ \\
\hline $\begin{array}{l}\text { Анг- } \\
\text { лия [5] }\end{array}$ & $\begin{array}{l}\text { Налог на } \\
\text { земельные } \\
\text { участки и } \\
\text { улучшения }\end{array}$ & \begin{tabular}{|l} 
Местный \\
бюджет
\end{tabular} & $\begin{array}{l}\text { Рыночная } \\
\text { стоимость, } \\
\text { установлен- } \\
\text { ная в } 1991 \text { г. }\end{array}$ & $\begin{array}{l}\text { До } 120 \text { тыс. фунтов стерлингов } \\
\text { не облагается налогом, от } 120 \text { до } \\
250 \text { тыс. фунтов - по ставке } 1 \% \text {, } \\
\text { от } 250 \text { до } 500 \text { тыс. фунтов - } 3 \% \text {, } \\
\text { свыше } 500 \text { тыс. фунтов - от } 4 \%\end{array}$ & $\begin{array}{l}\text { Земельные } \\
\text { участки и } \\
\text { улучшения }\end{array}$ & $\begin{array}{l}\text { Собственни- } \\
\text { ки или арен- } \\
\text { даторы не- } \\
\text { движимого } \\
\text { имущества } \\
\text { (в том числе } \\
\text { жилья) }\end{array}$ \\
\hline
\end{tabular}


Продолжение таблицьь

\begin{tabular}{|c|c|c|c|c|c|c|}
\hline Страна & Вид налога & $\begin{array}{c}\text { Получатель } \\
\text { налога }\end{array}$ & $\begin{array}{c}\text { Налогообла- } \\
\text { гаемая база }\end{array}$ & Ставка налога & $\begin{array}{l}\text { Объект нало- } \\
\text { гообложения }\end{array}$ & $\begin{array}{c}\text { Плательщик } \\
\text { налога }\end{array}$ \\
\hline \multirow[t]{6}{*}{$\begin{array}{l}\text { Франция } \\
{[14]}\end{array}$} & \begin{tabular}{|l|} 
Ежегодный \\
налог на \\
проживание \\
(Tахе \\
d'habitation) \\
[6] \\
\end{tabular} & $\begin{array}{l}\text { Местный } \\
\text { бюджет }\end{array}$ & $\begin{array}{l}\text { Условная } \\
\text { арендная пла- } \\
\text { та жилья (го- } \\
\text { раздо ниже } \\
\text { рыночной) }\end{array}$ & $\begin{array}{l}\text { Арендная плата за } 1 \text { месяц. } \\
\text { В зависимости от семейного по- } \\
\text { ложения налогоплательщика } \\
\text { предоставляются льготы, до } \\
\text { полного освобождения от налога }\end{array}$ & $\begin{array}{l}\text { Жилые по- } \\
\text { мещения }\end{array}$ & \begin{tabular}{|l|} 
Физическое \\
лицо, прожи- \\
вающее в жи- \\
лом помеще- \\
нии на начало \\
года \\
\end{tabular} \\
\hline & $\begin{array}{l}\text { Ежегодный } \\
\text { налог на не- } \\
\text { движимость } \\
\text { (Taxe } \\
\text { foncière) }\end{array}$ & $\begin{array}{l}\text { Местный } \\
\text { бюджет }\end{array}$ & $\begin{array}{l}\text { Условная } \\
\text { арендная пла- } \\
\text { та жилья }\end{array}$ & $\begin{array}{l}\text { Арендная плата за } 0,5-1,5 \text { месяца. } \\
\text { Ставка taxe foncière } 0,5 \text { месяца } \\
\text { аренды, если в городе, в котором } \\
\text { находится жилье, есть предпри- } \\
\text { ятия. В населенных пунктах, ко- } \\
\text { торые слабее развиты экономи- } \\
\text { чески, ставка равна плате за } \\
1,5 \text { месяца }\end{array}$ & $\begin{array}{l}\text { Жилые по- } \\
\text { мещения }\end{array}$ & $\begin{array}{l}\text { Собствен- } \\
\text { ник - физи- } \\
\text { ческое лицо }\end{array}$ \\
\hline & \begin{tabular}{|l|} 
Налог на \\
пустующую \\
недвижи- \\
мость \\
(lataxesurles1 \\
ogementsvac \\
ants, TLV) \\
\end{tabular} & $\begin{array}{l}\text { Местный } \\
\text { бюджет }\end{array}$ & $\begin{array}{l}\text { Арендный до- } \\
\text { ход, рассчи- } \\
\text { тываемый на } \\
\text { основании } \\
\text { данных рынка }\end{array}$ & $\begin{array}{l}\text { Если жилье не занято более года, } \\
\text { ставка составляет } 12,5 \% \text {, более - } \\
25 \%\end{array}$ & $\begin{array}{l}\text { Жилые по- } \\
\text { мещения }\end{array}$ & $\begin{array}{l}\text { Собствен- } \\
\text { ник - физи- } \\
\text { ческое лицо }\end{array}$ \\
\hline & $\begin{array}{l}\text { Налог на } \\
\text { недвижи- } \\
\text { мость (кос- } \\
\text { венное вла- } \\
\text { дение) } \\
\end{array}$ & $\begin{array}{l}\text { Местный } \\
\text { бюджет }\end{array}$ & $\begin{array}{l}\text { Рыночная } \\
\text { стоимость }\end{array}$ & $\begin{array}{l}\text { Для французских компаний - } \\
1,5 \% \text {; } \\
\text { для иностранных компаний - } \\
3 \% \text { [11] }\end{array}$ & $\begin{array}{l}\text { Недвижи- } \\
\text { мость }\end{array}$ & $\begin{array}{l}\text { Собствен- } \\
\text { ник - юриди- } \\
\text { ческое лицо }\end{array}$ \\
\hline & $\begin{array}{l}\text { Налог на } \\
\text { застроенные } \\
\text { участки }\end{array}$ & $\begin{array}{l}\text { Местный } \\
\text { бюджет }\end{array}$ & $\begin{array}{l}50 \% \text { стоимо- } \\
\text { сти условной } \\
\text { арендной пла- } \\
\text { ты }\end{array}$ & $\begin{array}{l}\text { Коэффициенты, устанавливае- } \\
\text { мые органами местного само- } \\
\text { управления. Например, для Па- } \\
\text { рижа - 7,98 \% [3]. } \\
\text { От уплаты освобождаются: го- } \\
\text { сударственная собственность; } \\
\text { здания, предназначенные для } \\
\text { сельскохозяйственного исполь- } \\
\text { зования; физические лица стар- } \\
\text { ше } 75 \text { лет }\end{array}$ & $\begin{array}{l}\text { Недвижи- } \\
\text { мость и зе- } \\
\text { мельные уча- } \\
\text { стки, предна- } \\
\text { значенные } \\
\text { для промыш- } \\
\text { ленного или } \\
\text { коммерческо- } \\
\text { го использо- } \\
\text { вания } \\
\end{array}$ & $\begin{array}{l}\text { Собствен- } \\
\text { ник - юриди- } \\
\text { ческое или } \\
\text { физическое } \\
\text { лицо }\end{array}$ \\
\hline & $\begin{array}{l}\text { Налог на } \\
\text { незастроен- } \\
\text { ные участки }\end{array}$ & $\begin{array}{l}\text { Местный } \\
\text { бюджет }\end{array}$ & $\begin{array}{l}80 \text { \% стоимо- } \\
\text { сти условной } \\
\text { арендной пла- } \\
\text { ты }\end{array}$ & $\begin{array}{l}\text { Коэффициенты, устанавливае- } \\
\text { мые органами местного само- } \\
\text { управления. Например, для Па- } \\
\text { рижа - } 15 \text { \%. } \\
\text { От уплаты освобождаются уча- } \\
\text { стки в государственной собст- } \\
\text { венности, могут временно осво- } \\
\text { бождаться участки, предназна- } \\
\text { ченные под развитие сельскохо- } \\
\text { зяйственного производства }\end{array}$ & $\begin{array}{l}\text { Земельные и } \\
\text { лесные уча- } \\
\text { стки, нахо- } \\
\text { дящиеся в } \\
\text { частной соб- } \\
\text { ственности }\end{array}$ & Собственник \\
\hline
\end{tabular}


О.В. Лихоманов, Н.Е. Куканова, М.С. Куканова. Практика оценки муниципальной недвижимости

Продолжение таблиць

\begin{tabular}{|c|c|c|c|c|c|c|}
\hline Страна & Вид налога & \begin{tabular}{|c|} 
Получатель \\
налога
\end{tabular} & $\begin{array}{c}\text { Налогообла- } \\
\text { гаемая база }\end{array}$ & Ставка налога & $\begin{array}{l}\text { Объект нало- } \\
\text { гообложения }\end{array}$ & $\begin{array}{c}\text { Плательщик } \\
\text { налога } \\
\end{array}$ \\
\hline \begin{tabular}{|l} 
Герма- \\
ния
\end{tabular} & \begin{tabular}{|l} 
Налог на \\
недвижимое \\
имущество, \\
вне зависи- \\
мости от его \\
назначения
\end{tabular} & $\begin{array}{l}\text { Местный } \\
\text { бюджет }\end{array}$ & \begin{tabular}{|l|} 
Оценочная \\
стоимость \\
имущества \\
(Еinheitswert) \\
[4]: \\
- совокупная \\
стоимость \\
земельного \\
участка и \\
улучшений \\
на единую \\
временную \\
дату: \\
- для Запад- \\
ной Германии \\
-01.011964 г.; \\
- для терри- \\
тории быв- \\
шей ГдР - \\
01.011935 г. \\
[13]. \\
Как правило, \\
оценочная \\
значительно \\
ниже рыноч- \\
ной стоимо- \\
сти
\end{tabular} & $\begin{array}{l}\text { Базовая федеральная ставка еже- } \\
\text { годного налога на недвижимость } \\
\text { (Grundsteuer) составляет от } \\
2,6 \text { до } 3,5 \text { \% для западных феде- } \\
\text { ральных земель, от } 5 \text { до } 10 \text { \% для } \\
\text { восточных федеральных земель } \\
\text { и } 6 \% \text { для сельского и лесного } \\
\text { хозяйства [15]. } \\
\text { Результат умножается на мест- } \\
\text { ный коэффициент, который мо- } \\
\text { жет составлять от } 280 \text { до } 810 \% \text { \%. } \\
\text { Например, во Франкфурте мно- } \\
\text { житель равен } 460 \% \text { Гамбурге - } \\
540 \% \text { [18]; Дортмунде - 610 \% } \\
\text { [17]; Берлине - } 810 \% \text { \% [16]. } \\
\text { Конечная ставка составляет от } \\
0,98 \text { до 2,1 \% оценочной стоимо- } \\
\text { сти имущества. Средняя ставка } \\
\text { составляет около } 1,5 \%\end{array}$ & $\begin{array}{l}\text { Недвижимое } \\
\text { имущество, } \\
\text { вне зависи- } \\
\text { мости от его } \\
\text { назначения }\end{array}$ & 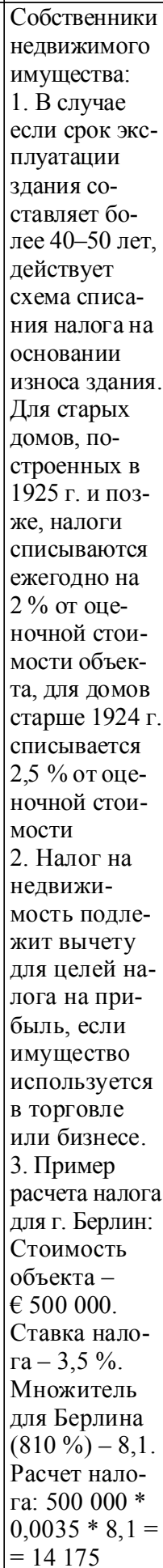 \\
\hline
\end{tabular}


Продолжение таблицьь

\begin{tabular}{|c|c|c|c|c|c|c|}
\hline Страна & Вид налога & \begin{tabular}{|c|} 
Получатель \\
налога
\end{tabular} & $\begin{array}{c}\text { Налогообла- } \\
\text { гаемая база }\end{array}$ & Ставка налога & $\begin{array}{l}\text { Объект нало- } \\
\text { гообложения }\end{array}$ & $\begin{array}{c}\text { Плательщик } \\
\text { налога }\end{array}$ \\
\hline $\begin{array}{l}\text { США } \\
{[14]}\end{array}$ & $\begin{array}{l}\text { Налог на } \\
\text { земельно- } \\
\text { имущест- } \\
\text { венный } \\
\text { комплекс }\end{array}$ & $\begin{array}{l}\text { Местный } \\
\text { бюджет }\end{array}$ & $\begin{array}{l}50 \text { \% от ры- } \\
\text { ночной стои- } \\
\text { мости. } \\
\text { Земельный } \\
\text { участок и } \\
\text { строения на } \\
\text { нем оценива- } \\
\text { ются по от- } \\
\text { дельности } \\
\end{array}$ & $\begin{array}{l}\text { Примерно } 1 \text { \% (в соответствии с } \\
\text { законами штата) }\end{array}$ & $\begin{array}{l}\text { Земельно- } \\
\text { имуществен- } \\
\text { ный комплекс }\end{array}$ & $\begin{array}{l}\text { Собственни- } \\
\text { ки недвижи- } \\
\text { мого имуще- } \\
\text { ства }\end{array}$ \\
\hline $\begin{array}{l}\text { Кана- } \\
\text { да }[14]\end{array}$ & \begin{tabular}{|l} 
Налог на \\
земельно- \\
имущест- \\
венный \\
комплекс \\
\end{tabular} & $\begin{array}{l}\text { Местный } \\
\text { бюджет }\end{array}$ & $\begin{array}{l}50 \text { \% рыноч- } \\
\text { ной стоимо- } \\
\text { сти }\end{array}$ & $1 \%$ & $\begin{array}{l}\text { Земельно- } \\
\text { имуществен- } \\
\text { ный комплекс }\end{array}$ & $\begin{array}{l}\text { Собственни- } \\
\text { ки недвижи- } \\
\text { мого имуще- } \\
\text { ства }\end{array}$ \\
\hline $\begin{array}{l}\text { Шве- } \\
\text { ция [8] }\end{array}$ & $\begin{array}{l}\text { Налог на } \\
\text { недвижи- } \\
\text { мость }\end{array}$ & $\begin{array}{l}\text { Местный } \\
\text { бюджет }\end{array}$ & $\begin{array}{l}75 \text { \% рыноч- } \\
\text { ной стоимо- } \\
\text { сти }\end{array}$ & $1,7 \%$ & $\begin{array}{l}\text { Объект не- } \\
\text { движимости }\end{array}$ & $\begin{array}{l}\text { Собственни- } \\
\text { ки недвижи- } \\
\text { мого имуще- } \\
\text { ства }\end{array}$ \\
\hline \multirow[t]{3}{*}{$\begin{array}{l}\text { Да- } \\
\text { ния [1] }\end{array}$} & $\begin{array}{l}\text { Налог на } \\
\text { жилую не- } \\
\text { движимость }\end{array}$ & $\begin{array}{l}\text { Местный } \\
\text { бюджет }\end{array}$ & $\begin{array}{l}\text { Рыночная } \\
\text { стоимость }\end{array}$ & От 0,6 до $2,4 \%$ & $\begin{array}{l}\text { Стоимость } \\
\text { здания, без } \\
\text { земли }\end{array}$ & $\begin{array}{l}\text { Собственни- } \\
\text { ки недвижи- } \\
\text { мого имуще- } \\
\text { ства }\end{array}$ \\
\hline & $\begin{array}{l}\text { Земельный } \\
\text { налог }\end{array}$ & $\begin{array}{l}\text { Окружной } \\
\text { бюджет } \\
\end{array}$ & $\begin{array}{l}\text { Рыночная } \\
\text { стоимость }\end{array}$ & $1 \%$ & $\begin{array}{l}\text { Стоимость } \\
\text { только земли } \\
\end{array}$ & $\begin{array}{l}\text { Собственни- } \\
\text { ки земли }\end{array}$ \\
\hline & $\begin{array}{l}\text { Налог на } \\
\text { недвижи- } \\
\text { мость, ис- } \\
\text { пользуемую } \\
\text { под ком- } \\
\text { мерческие } \\
\text { цели }\end{array}$ & $\begin{array}{l}\text { Местный } \\
\text { бюджет }\end{array}$ & $\begin{array}{l}\text { Рыночная } \\
\text { стоимость }\end{array}$ & $1 \%$ & $\begin{array}{l}\text { Земельно- } \\
\text { имуществен- } \\
\text { ный комплекс }\end{array}$ & $\begin{array}{l}\text { Собственни- } \\
\text { ки недвижи- } \\
\text { мого имуще- } \\
\text { ства }\end{array}$ \\
\hline $\begin{array}{l}\text { Голлан- } \\
\text { дия [1] }\end{array}$ & $\begin{array}{l}\text { Налог на } \\
\text { недвижи- } \\
\text { мость }\end{array}$ & $\begin{array}{l}\text { Местный } \\
\text { бюджет }\end{array}$ & $\begin{array}{l}\text { Налогообла- } \\
\text { гаемая база } \\
\text { устанавлива- } \\
\text { ется государ- } \\
\text { ственной } \\
\text { оценкой }\end{array}$ & $0,1-0,9 \%$ стоимости & $\begin{array}{l}\text { Налог на не- } \\
\text { движимость } \\
\text { состоит из } \\
\text { двух частей, } \\
\text { взимаемых и } \\
\text { с собствен- } \\
\text { ников и с } \\
\text { пользовате- } \\
\text { лей недви- } \\
\text { жимости }\end{array}$ & $\begin{array}{l}\text { Собственни- } \\
\text { ки и пользо- } \\
\text { ватели не- } \\
\text { движимости }\end{array}$ \\
\hline \begin{tabular}{|l} 
Испания \\
{$[1]$}
\end{tabular} & \begin{tabular}{|l} 
Налог на \\
земельно- \\
имущест- \\
венный \\
комплекс \\
\end{tabular} & $\begin{array}{l}\text { Местный } \\
\text { бюджет }\end{array}$ & $\begin{array}{l}\text { Кадастровая } \\
\text { стоимость }\end{array}$ & $\begin{array}{l}\text { 0,4 \% для имущества, находяще- } \\
\text { гося в городе; } \\
0,3 \text { \% для имущества, находяще- } \\
\text { гося в сельской местности }\end{array}$ & $\begin{array}{l}\text { Земельно- } \\
\text { имуществен- } \\
\text { ный комплекс }\end{array}$ & $\begin{array}{l}\text { Собственни- } \\
\text { ки недвижи- } \\
\text { мости }\end{array}$ \\
\hline \begin{tabular}{|l|} 
Порту- \\
галия [7]
\end{tabular} & \begin{tabular}{|l} 
Налог на \\
земельно- \\
имущест- \\
венный \\
комплекс \\
\end{tabular} & $\begin{array}{l}\text { Местный } \\
\text { бюджет }\end{array}$ & $\begin{array}{l}\text { Кадастровая } \\
\text { стоимость }\end{array}$ & $\begin{array}{l}\text { 0,2-0,8 \% от кадастровой стои- } \\
\text { мости объекта, устанавливаемой } \\
\text { ежегодно местными законода- } \\
\text { тельными органами }\end{array}$ & $\begin{array}{l}\text { Земельно- } \\
\text { имуществен- } \\
\text { ный комплекс }\end{array}$ & $\begin{array}{l}\text { Собственни- } \\
\text { ки недвижи- } \\
\text { мости }\end{array}$ \\
\hline
\end{tabular}


Окончание таблиць

\begin{tabular}{|c|c|c|c|c|c|c|}
\hline Страна & Вид налога & \begin{tabular}{|c|} 
Получатель \\
налога
\end{tabular} & $\begin{array}{l}\text { Налогообла- } \\
\text { гаемая база }\end{array}$ & Ставка налога & $\begin{array}{l}\text { Объект нало- } \\
\text { гообложения }\end{array}$ & $\begin{array}{c}\text { Плательщик } \\
\text { налога }\end{array}$ \\
\hline \begin{tabular}{|l|} 
Филип- \\
пины [14]
\end{tabular} & $\begin{array}{l}\text { Налог на } \\
\text { земельно- } \\
\text { имущест- } \\
\text { венный } \\
\text { комплекс }\end{array}$ & $\begin{array}{l}\text { Местный } \\
\text { бюджет }\end{array}$ & $\begin{array}{l}\text { Кадастровая } \\
\text { стоимость }\end{array}$ & $\begin{array}{l}\text { Земельные участки жилого назна- } \\
\text { чения - } 20 \% \text {, коммерческого на- } \\
\text { значения - } 50 \text { \%, сельскохозяйст- } \\
\text { венного назначения - } 40 \text { \%. } \\
\text { Шкала для недвижимого имуще- } \\
\text { ства прогрессивная: в зависимо- } \\
\text { сти от его стоимости. } \\
\text { От налога освобождается иму- } \\
\text { щество, используемое в образо- } \\
\text { вательных, религиозных и бла- } \\
\text { готворительных целях }\end{array}$ & $\begin{array}{l}\text { Земельно- } \\
\text { имуществен- } \\
\text { ный комплекс }\end{array}$ & $\begin{array}{l}\text { Собственни- } \\
\text { ки недвижи- } \\
\text { мого имуще- } \\
\text { ства }\end{array}$ \\
\hline Чили [14] & $\begin{array}{l}\text { Земельно- } \\
\text { имущест- } \\
\text { венный } \\
\text { комплекс } \\
\end{array}$ & $\begin{array}{l}\text { Местный } \\
\text { бюджет }\end{array}$ & $\begin{array}{l}\text { Кадастровая } \\
\text { стоимость }\end{array}$ & $\begin{array}{l}1,1 \text { \% для имущества, находяще- } \\
\text { гося в городе; } \\
2 \text { \% для имущества, находящего- } \\
\text { ся в сельской местности } \\
\end{array}$ & $\begin{array}{l}\text { Земельно- } \\
\text { имуществен- } \\
\text { ный комплекс }\end{array}$ & $\begin{array}{l}\text { Собственни- } \\
\text { ки недвижи- } \\
\text { мого имуще- } \\
\text { ства } \\
\end{array}$ \\
\hline $\begin{array}{l}\text { Респуб- } \\
\text { лика } \\
\text { Синга- } \\
\text { пур [14] }\end{array}$ & \begin{tabular}{|l|} 
Налог на \\
недвижимое \\
имущество
\end{tabular} & $\begin{array}{l}\text { Местный } \\
\text { бюджет }\end{array}$ & \begin{tabular}{|l|} 
Расчетная \\
сумма, кото- \\
рую можно \\
получить за \\
год при сдаче \\
недвижимо- \\
сти в аренду \\
\end{tabular} & $\begin{array}{l}12 \text { \% для имущества, используе- } \\
\text { мого в коммерческих или произ- } \\
\text { водственных целях; } \\
4 \text { \% для жилого имущества }\end{array}$ & $\begin{array}{l}\text { Недвижимое } \\
\text { имущество }\end{array}$ & $\begin{array}{l}\text { Собственни- } \\
\text { ки недвижи- } \\
\text { мого имуще- } \\
\text { ства }\end{array}$ \\
\hline $\begin{array}{l}\text { Япо- } \\
\text { ния [1] }\end{array}$ & \begin{tabular}{|l|} 
Налог на \\
недвижимое \\
имущество
\end{tabular} & $\begin{array}{l}\text { Местный } \\
\text { бюджет }\end{array}$ & $\begin{array}{l}\text { Кадастровая } \\
\text { стоимость } \\
\text { имущества }\end{array}$ & $1,4 \%$ & $\begin{array}{l}\text { Недвижимое } \\
\text { имущество }\end{array}$ & $\begin{array}{l}\text { Собственни- } \\
\text { ки недвижи- } \\
\text { мого имуще- } \\
\text { ства } \\
\end{array}$ \\
\hline \begin{tabular}{|l|} 
Поль- \\
ша [10]
\end{tabular} & \begin{tabular}{|l|} 
Налог на \\
недвижимое \\
имущество \\
\end{tabular} & $\begin{array}{l}\text { Местный } \\
\text { бюджет }\end{array}$ & $\begin{array}{l}\text { Кадастровая } \\
\text { стоимость } \\
\text { имущества }\end{array}$ & $\begin{array}{l}\text { Максимальные ставки налога: } \\
0,16-0,20 € \text { за } 1 \text { м² в год для жи- } \\
\text { лых помещений (квартиры); } \\
3,9 € \text { за } 1 \text { м² в год для коммерче- } \\
\text { ской недвижимости, } \\
-0,002 € \text { за } 1 \text { м² в год для зе- } \\
\text { мельных участков }\end{array}$ & \begin{tabular}{|l} 
Недвижимое \\
имущество
\end{tabular} & $\begin{array}{l}\text { Собственни- } \\
\text { ки недвижи- } \\
\text { мого имуще- } \\
\text { ства }\end{array}$ \\
\hline
\end{tabular}

Примечания. Источники: [1;3-18].

Следует отметить:

- в Японии пересмотр стоимости производится раз в три года;

- в Испании кадастровая стоимость переоценивается каждые 8 лет государственной структурой;

- во Франции кадастровая стоимость (не меняется в течение последних 50 лет);

- в США переоценка недвижимости на основе рыночных цен в целях налогообложения проводится ежегодно;

- субъекты РФ, согласно ст. 378.2 и 402 НК РФ, могут самостоятельно определять дату перехода к налогообложению недвижимости физических лиц и организаций по кадастровой стоимости. С 2017 г. налогообложение недвижимости исходя из кадастровой стоимости будет осуществляться в 72 субъектах РФ. Волгоградской области в этом перечне нет.

Создание эффективной системы управления муниципальным недвижимым имуществом предполагает совершенствование качества местного самоуправления и подразумевает следующие мероприятия:

1. Организация и бесперебойное функционирование полноценного и своевременного учета муниципального недвижимого имущества, внедрение автоматизированной системы ведения реестров, включая правовую, техническую и экономическую составляющие учета.

2. Разработка и функционирование научно обоснованных оптимальных управленческих решений по распоряжению имущества, находящегося в муниципальной собственности, при соблюдении баланса фискальных, инвестиционных и социально ориентированных целей, при оперативном управлении, передаче в пользование или доверительное управление, 
отчуждении, использовании в качестве уставного капитала.

3. Принятие оптимальных решений для выбора стратегий по достижению максимальной экономической эффективности использования и повышения инвестиционной привлекательности муниципальной недвижимости.

4. Осуществление эффективного контроля за нормативным использованием муниципального имущества (особенно земельных ресурсов) по его назначению.

5. Организация работы по определению достоверной величины кадастровой стоимости недвижимости.

6. Обеспечение государственных бюджетных учреждений по оценке кадастровой стоимости, создаваемых в регионах, квалифицированными кадрами из числа практикующих независимых оценщиков. Привлечение независимых оценщиков для анализа и мониторинга рынка недвижимости с целью выявления ценообразующих факторов и обеспечения достоверных результатов, соответствующих рыночным данным.

7. Полное исключение возможности давления должностных лиц органов местного самоуправления на государственные бюджетные учреждения по оценке кадастровой стоимости с целью установления желательных ориентиров кадастровой стоимости.

8. Инициирование:

- введения единой даты установления кадастровой стоимости на территории Российской Федерации с целью обеспечения единого инвестиционного пространства;

- установления в качестве эксперимента в нескольких регионах РФ налоговой базы для земельного налога и налога на имущество на уровне 50-75 \% от кадастровой (приближенной к рыночной) стоимости с целью выявления оптимального налогового потенциала налогоплательщиков исходя из принципов справедливости и соразмерности налогообложения.

\section{ПРИМЕЧАНИЕ}

1 Исследование выполнено при финансовой поддержке РФФИ и Администрации Волгоградской области в рамках научно-исследовательского проекта № 16-12-34020/16 «Формирование и регулирование рынка трудовых ресурсов Волгоградс- кой области в условиях функционирования Евразийского экономического союза».

\section{СПИСОК ЛИТЕРАТУРЫ}

1. Епифанцева, А. С. Налогообложение недвижимости в период модернизации / А. С. Епифанцева. - Электрон. текстовые дан. - Режим доступа: http://www.scienceforum.ru/2014/502/773. - Загл. с экрана.

2. Лихоманов, О. В. Анализ адекватности кадастровой стоимости объектов недвижимости рыночным условиям (на примере Волгоградского региона) / О. В. Лихоманов, М.С.Куканова // Вестник Волгоградского государственного университета. Серия 3, Экономика. Экология. - 2016. - № 3 (36). C. 145-154. - DOI: https://doi.org/10.15688/ jvolsu3.2016.3.14.

3. Местные налоги во Франции. - Электрон. текстовые дан. - Режим доступа: http://www.scien ceforum.ru/2014/discus/632/2391. - Загл. с экрана.

4. Налог на недвижимость в Германии. Электрон. текстовые дан. - Режим доступа: http:/ /nedvigimostmsk.ru/procedura-pokupki-v-germanii/ nalog-na-nedvizhimost-v-germanii.html. - Загл. с экрана.

5. Налог на роскошь: на кого России равняться? - Электрон. текстовые дан. - Режим доступа: http://www.vestifinance.ru/articles/7402. Загл. с экрана.

6. Налоги во Франции: за что платят резиденты и зарубежные покупатели недвижимости. Электрон. текстовые дан. - Режим доступа: https:// tranio.ru/france/analytics/nalogi_vo_francii_za_ chto_platyat_rezidenty_i_zarubezhnye_pokupateli_ nedvizhimosti_3709. - Загл. с экрана.

7. Налоги для покупателей и собственников недвижимости в Португалии. - Электрон. текстовые дан. - Режим доступа: http://ee24.ru/portugal/ information/taxes. - Загл. с экрана.

8. Налоги Швеции. - Электрон. текстовые дан. - Режим доступа: http://fin-buh.ru/text/852331.html. - Загл. с экрана.

9. Налоговый кодекс Российской Федерации(часть вторая) от 05.08.2000 № 117-ФЗ.

10. Недвижимость в Польше: инвестиции в центре Европы. - Электрон. текстовые дан. - Режим доступа: http://www.zametrami.ru/evropa/ nedvizhimost-v-polshe-slavyanskaya-strana-v-centreevropy. - Загл. с экрана.

11. Особенности налоговой системы Франции. - Электрон. текстовые дан. - Режим доступа: http://isfic.info/fornal/velia13.htm. - Загл. с экрана.

12. Решение Волгоградской городской Думы от 27.04.2016 № 43/1269 «О внесении изменений в 
Положение о местных налогах на территории Волгограда, принятое постановлением Волгоградского городского Совета народных депутатов от 23.11.2005 № 24/464 “'О Положении о местных налогах на территории Волгограда, введении системы налогообложения в виде единого налога на вмененный доход, установлении и введении местных налогов на территории Волгограда" (в редакции на 08.04.2015)». - Электрон. текстовые дан. - Режим доступа: http://www.volgsovet.ru/c2t5/Act/Decision/ 2016/4008. - Загл. с экрана.

13. Хлопцов, Д. М. Оценка недвижимости в целях налогообложения: опыт Германии / Д. М. Хлопцов // Имущественные отношения в РФ. - 2013. № 9 (144). - Электрон. текстовые дан. - Режим доступа: http://cyberleninka.ru/article/n/otsenkanedvizhimosti-v-tselyah-nalogooblozheniya-opytgermanii. - Загл. с экрана.

14. Ходов, Л. Г. Налоги на недвижимость: зарубежный опыт, российские проблемы / Л. Г. Ходов. - Электрон. текстовые дан. - Режим доступа: http://www.studmed.ru/hodov-lg-nalogi-nanedvizhimost-zarubezhnyy-opyt-rossiyskie-problemy _f9e0a3c161a.html. - Загл. с экрана.

15. Global property guide. - Electronic text data. Mode of access: http://www.global propertyguide. com/Europe/Germany/Taxes-and-Costs. - Title from screen.

16. Grundsteuer in Berlin. - Electronic text data. Mode of access: https://www.ihk-berlin.de/blob/bihk 24/Service-und-Beratung/recht und steuern/ downloads/2253346/1 f0c8b238b58033ba9df3ee $821939455 /$ Merkblatt Grundsteue r in Berlin-data. pdf. - Title from screen.

17. Grundsteuer. - Electronic text data. - Mode of access: https://www.dortmund.de/de/rathaus_und buergerservice/stadtverwaltung_zentrale_aufgaben/ stadtkasse_und_steueramt/abgabearten/grundbesit zabgaben/grundsteuer. - Title from screen.

18. Handelskammer Hamburg. - Electronic text data. - Mode of access: https://www.hk24.de/ produktmarken/beratung-service/recht_und_steuern/ steuerrecht/real_kommunale_steuern/grundsteuer/ 1157150. - Title from screen.

\section{REFERENCES}

1. Epifantseva A.S. Nalogooblozhenie nedvizhimosti $v$ period modernizatsii [Property Taxation in the Period of Modernization]. URL: http:// www.scienceforum.ru/2014/502/773.

2. Likhomanov O.V., Kukanova M.S. Analiz adekvatnosti kadastrovoy stoimosti obyektov nedvizhimosti rynochnym usloviyam (na primere Volgogradskogo regiona) [Analysis of the Adequacy of Real Estate Cadastral Value to Market Conditions (on the Example of the Volgograd Region)]. Vestnik Volgogradskogo gosudarstvennogo universiteta. Seriya 3, Ekonomika. Ekologiya [Science Journal of Volgograd State University. Global Economic System], 2016, no. 3 (36), pp. 145-154. DOI: https://doi.org/ 10.15688/jvolsu3.2016.3.14.

3. Mestnye nalogi vo Frantsii [Local Taxes in France]. URL: http://www.scienceforum.ru/2014/ discus/632/2391.

4. Nalog na nedvizhimost $v$ Germanii [Real Estate Tax in Germany]. URL: http://nedvigimostmsk.ru/ procedura-pokupki-v-germanii/nalog-na-nedvizhimostv-germanii.html.

5. Nalog na roskosh: na kogo Rossii ravnyatsya? [The Tax on Luxury: Who Should Look up to?]. URL: http://www.vestifinance.ru/articles/7402.

6. Nalogi vo Frantsii: za chto platyat rezidenty $i$ zarubezhnye pokupateli nedvizhimosti [Tax in France: What do Residents and Foreign Buyers of Real Estate Pay for?]. URL: https://tranio.ru/france/ analytics/nalogi_vo_francii_za_chto_platyat rezidenty_i_zarubezhnye_pokupateli_nedvizhimosti_ 3709 .

7. Nalogi dlya pokupateley i sobstvennikov nedvizhimosti v Portugalii [Taxes for Buyers and Owners of Real Estate in Portugal]. URL: http://ee24.ru/ portugal/information/taxes.

8. Nalogi Shvecii [The Swedish Tax]. URL: http:/ /fin-buh.ru/text/85233-1.html.

9. Nalogovyy kodeks Rossiyskoy Federatsii (chast vtoraya) ot 05.08.2000 № 117-FZ [The Russian Tax Code (Part II) of August 5, 2000 no. 117-FL].

10. Nedvizhimost v Polshe: investitsii v tsentre Evropy [Real Estate in Poland: Investment in the Centre of Europe]. URL: http://www.zametrami.ru/evropa/ nedvizhimost-v-polshe-slavyanskaya-strana-v-centreevropy.

11. Osobennosti nalogovoy sistemy Frantsii [Features of the French Tax System]. URL: http:// isfic.info/fornal/velia13.htm.

12. Reshenie Volgogradskoy gorodskoy Dumy ot 27.04.2016 № 43/1269 «O vnesenii izmeneniy v Polozhenie o mestnykh nalogakh na territorii Volgograda, prinyatoe postanovleniem Volgogradskogo gorodskogo Soveta narodnykh deputatov ot 23.11.2005 № 24/464 "O Polozhenii o mestnykh nalogakh na territorii Volgograda, vvedenii sistemy nalogooblozheniya v vide edinogo naloga na vmenennyy dokhod, ustanovlenii $i$ vvedenii mestnykh nalogov na territorii Volgograda" (v redaktsii na 08.04.2015)» [Decision of the Volgograd City Duma of April 27, 2016 no. 43/1269 “On Amendments to the Provision on Local Taxes in the Territory of Volgograd, Adopted by the Resolution of Volgograd City Council of People's Deputies of 
November 23, 2005 no. 24/464 "On the Provision on Local Taxes in the Territory of Volgograd, Introduction of the Taxation System in the Form of a Single Tax on Imputed Income, Establishment and Introduction of Local Taxes in the Territory of Volgograd" (amend. of April 8, 2015)"]. URL: http://www.volgsovet.ru/c2t5/ Act/Decision/2016/4008.

13. Khloptsov D.M. Otsenka nedvizhimosti v tselyakh nalogooblozheniya: opyt Germanii [Evaluation of Property for Tax Purposes: the German Experience]. Imushchestvennye otnosheniya $v R F, 2013$, no. 9 (144). URL: http://cyberleninka.ru/article/n/otsenkanedvizhimosti-v-tselyah-nalogooblozheniya-opytgermanii.

14. Khodov L.G. Nalogi na nedvizhimost: zarubezhnyy opyt, rossiyskie problemy [Property Taxes: Foreign Experience, Russian Problems]. URL: http://www.studmed.ru/hodov-lg-nalogi-na- nedvizhimost-zarubezhnyy-opyt-rossiyskieproblemy_9e0a3c161a.html.

15. Global property guide. URL: http:// www.globalpropertyguide.com/Europe/Germany/ Taxes-and-Costs.

16. Grundsteuer in Berlin. URL: https://www.ihkberlin.de/blob/bihk24/Service-und-Beratung/ recht_und_steuern/downloads/2253346/1 f0c8b238 b58033ba9df3ee821939455/Merkblatt_Grundsteuer _in_Berlin-data.pdf.

17. Grundsteuer. URL: https://www.dortmund. de/de/rathaus_und_buergerservice/stadtverwaltung _zentrale_aufgaben/stadtkasse_und_steueramt/ abgabearten/grundbesitzabgaben/grundsteuer/.

18. Handelskammer Hamburg. URL: https:// www.hk24.de/produktmarken/beratung-service/ recht_und_steuern/steuerrecht/real_kommunale _steuern/grundsteuer/1157150.

\section{Information About the Authors}

Oleg V. Likhomanov, Candidate of Sciences (Economics), Associate Professor, Department of Mathematical Methods and Computer Science in Economics, Volgograd State University, Prosp. Universitetsky, 100, 400062 Volgograd, Russian Federation, likhomanov.oleg@yandex.ru.

Natalya E. Kukanova, Chairman of the Board of the Volgograd Regional Branch of All-Russian Organization "Russian Society of Appraisers", Prosp. Universitetsky, 100, 400062 Volgograd, Russian Federation, virgo_ocenka@mail.ru.

Mariya S. Kukanova, Student, Institute of Management and Regional Economy, Volgograd State University, Prosp. Universitetsky, 100, 400062 Volgograd, Russian Federation, maha14396@yandex.ru.

\section{Информация об авторах}

Олег Владимирович Лихоманов, кандидат экономических наук, доцент кафедры математических методов и информатики в экономике, Волгоградский государственный университет, просп. Университетский, 100, 400062 г. Волгоград, Российская Федерация, likhomanov.oleg@yandex.ru.

Наталья Евгеньевна Куканова, председатель правления Волгоградского областного отделения Общероссийской организации «Российское общество оценщиков», просп. Университетский, 100, 400062 г. Волгоград, Российская Федерация, virgo_ocenka@mail.ru.

Мария Сергеевна Куканова, студент института управления и региональной экономики Волгоградского государственного университета, просп. Университетский, 100, 400062 г. Волгоград, Российская Федерация, maha14396@yandex.ru. 